\title{
Hypomelanosis of Ito and X;autosome translocations: a unifying hypothesis
}

\author{
Eli Hatchwell
}

\begin{abstract}
Hypomelanosis of Ito is a sporadic multisystem disorder known to be associated in many cases with chromosomal mosaicism. While no particular pattern is generally evident for the specific chromosomes involved in such patients, a subgroup of female patients exists in whom the common factor is the presence of a balanced, constitutional $X$;autosome translocation, with a cytogenetic breakpoint in the pericentromeric region of the $X$. It is argued here that the phenotype in these cases results not from the interruption of $\mathrm{X}$ linked genes but from the presence of mosaic functional disomy of $\mathbf{X}$ sequences above the breakpoint. ( $\mathcal{H}$ Med Genet 1996;33:177-183)
\end{abstract}

Key words: hypomelanosis of Ito; X;autosome translocation; functional disomy $\mathrm{Xp}$.

Hypomelanosis of Ito (HI) is a sporadic multisystem disorder whose defining feature is a pigmentary dysplasia. ${ }^{1}$ It is now clear that the common factor in many cases of $\mathrm{HI}$ is the presence of chromosomal mosaicism, although this is not an invariable finding. ${ }^{2-3}$ The frequent presence of chromosomal mosaicism in $\mathrm{HI}$ makes sense of the wide variability in clinical phenotype. In a review of over 70 published cases, the only consistent feature was the presence of hypopigmented skin without preceding vesicular or verrucous stages. ${ }^{4} \mathrm{~A}$ total of $74 \%$ of the patients, however, had one or more abnormalities of the central nervous system, eyes, hair, teeth, or musculoskeletal system. ${ }^{4}$ Such clinical variability is common to other mosaic genetic conditions (for example, Proteus syndrome $e^{5}$ ) and presumably reflects the variable presence of the genetically abnormal cell line within different lineages.

The description of a number of females milial incontinentia pigmenti is now designated IP2 (McKusick 308310). A reappraisal of familial incontinentia pigmenti (IP2) and the phenotypes described in females with $\mathrm{X}$;autosome translocations shows that there is very little overlap between the two; sporadic incontinentia pigmenti (IP1) does, however, resemble $\mathrm{HI}$ in the type and distribution of skin lesions, and in the occurrence of dysmorphic features, which are not present in IP2. ${ }^{16}{ }^{17}$ Some of the confusion between $\mathrm{HI}$ and incontinentia pigmenti has resulted from the alternative name for $\mathrm{HI}$, namely incontinentia pigmenti achromians. Given the clinical variability of $\mathrm{HI}$ alluded to above, there is little to distinguish cases of HI associated solely with autosomes from those related to $\mathrm{X}$;autosome translocations.

This paper reviews all cases of HI described in association with a balanced X;autosome translocation and puts forward a unifying hypothesis to explain the presence of this subgroup of patients. Evidence is considered for functional disomy of $\mathrm{X}$ sequences as the main aetiological factor in the appearance of the phenotype in such patients. It is proposed that the term incontinentia pigmenti should now be reserved for the familial form which maps to $\mathrm{Xq} 28$.

\section{$H I$ and $X$;autosome translocations}

In the rest of this review, females with "IP1" and $\mathrm{X}$;autosome translocations are referred to as having $\mathrm{HI}$. While $\mathrm{HI}$ is clearly heterogeneous in origin, the common factor is thought to be the presence of chromosomal mosaicism, although mosaic aneuploidy of almost any autosome or sex chromosome has been described. ${ }^{231819}$ In addition, it is likely that mosaicism for single gene defects can also give rise to HI. The existence of a subgroup with balanced X;autosome translocations and similar cytogenetic breakpoints on the $\mathrm{X}$ requires explanation. Table 1 lists all the females described so far with $\mathrm{HI}$ in association with a balanced X;autosome translocation. A thorough search of published reports indicated that HI has not been reported with any of the many $\mathrm{X}$;autosome translocations described with $\mathrm{X}$ breakpoints outside the interval Xq13$\mathrm{Xp} 11.21$.

Examination of table 1 shows the following points. (1) All the breakpoints involve the peri\footnotetext{
with balanced, constitutional $\mathrm{X}$;autosome translocations in association with a phenotype designated incontinentia pigmenti (IP1, McKusick 308300) prompted the suggestion that a locus for incontinentia pigmenti exists at the common cytogenetic breakpoint in Xp11. ${ }^{6-10}$ Linkage analysis in familial cases of incontinentia pigmenti, however, failed to confirm this cytogenetic localisation and much evidence now exists for the presence of a locus at Xq28. ${ }^{11-15}$ As a result of such analyses, fa-

Received 21 August 1995 Revised version accepted for publication

20 October 1995

Genetics Service Anne Hospital, Southampton Correspondence to: Corresponden
} 
Table 1 Summary of females with IP1/HI in association with balanced X;autosome translocations

\begin{tabular}{|c|c|c|c|c|c|c|c|c|c|c|c|}
\hline Karyotype & $\begin{array}{l}\begin{array}{l}\text { Gilgenkrantz } \\
\text { et al }\end{array} \\
46, X, t(X ; 9) \\
(p 11 ; q 34)\end{array}$ & $\begin{array}{l}\begin{array}{l}\text { Kajii } \\
\text { et al }\end{array} \\
46, X, t(X ; 13) \\
(p 11.21 ; q 12.3)\end{array}$ & $\begin{array}{l}\text { Hodgson } \\
\text { et } \text { al }^{\circ} \\
46, X, t(X ; 17) \\
(p 11.2 ; q 11.2)\end{array}$ & $\begin{array}{l}\text { Hodgson } \\
\text { et al }\end{array}$ & $\begin{array}{l}\text { Cannizzaro } \\
\text { and Hecht } \\
\text { et al }{ }^{1} \\
46, X, t(X ; 10) \\
(p 11 ; q 22)\end{array}$ & $\begin{array}{l}\begin{array}{l}\text { Lungarotti } \\
\text { et al }^{l^{\mathrm{s}}}\end{array} \\
46, X, t(X ; 18) \\
(p 11 ; q 23)\end{array}$ & $\begin{array}{l}\begin{array}{l}\text { Bitoun } \\
\text { et } a^{\circ}\end{array} \\
46, X, t(X ; 5) \\
(p 11.2 ; q 35.2)\end{array}$ & $\begin{array}{l}46, X, t(X ; 10) \\
(p 11 ; 11) m a t \|\end{array}$ & $\begin{array}{l}\text { Penchaszadeh } \\
\text { et al }\end{array}$ & $\begin{array}{l}\text { Sybert } \\
\text { et al } \\
46, X, t(X ; 22) \\
(p 11.2 ; q 13.3)\end{array}$ & $\begin{array}{l}\text { Steichen } \\
{\text { et } a l^{\prime 1}}^{1} \\
46, X, t(X ; 17) \\
(p 13 ; q 13)\end{array}$ \\
\hline \multicolumn{12}{|l|}{ Skin } \\
\hline Hypopigmentation & + & 0 & + & + & 0 & + & 0 & + & + & + & + \\
\hline Hyperpigmentation & $?$ & + & 0 & 0 & + & 0 & + & - & 0 & - & 0 \\
\hline $\begin{array}{l}\text { Blistering } \\
\text { CNS involvement }\end{array}$ & - & + & - & - & + & 0 & - & - & 0 & - & - \\
\hline Psychomotor delay & + & + & + & + & + & - & + & + & + & + & + \\
\hline Seizures & + & + & + & + & 0 & 0 & 0 & + & + & 0 & 0 \\
\hline EEG abnormalities & + & + & + & 0 & 0 & - & + & + & 0 & 0 & 0 \\
\hline Mental retardation & + & + & + & + & + & + & + & + & 0 & 0 & 0 \\
\hline Hypotonia & 0 & + & 0 & + & + & 0 & + & + & + & 0 & 0 \\
\hline Eye anomalies & 0 & + & + & + & 0 & 0 & - & + & 0 & 0 & + \\
\hline Teeth anomalies & - & 0 & + & + & + & 0 & - & + & 0 & 0 & 0 \\
\hline Hair anomalies & - & 0 & 0 & 0 & 0 & 0 & + & - & 0 & 0 & 0 \\
\hline Nail anomalies & - & 0 & 0 & 0 & 0 & 0 & 0 & + & 0 & 0 & 0 \\
\hline Cerebral anomalies & 0 & $*$ & $t$ & 0 & 0 & 0 & $\mathrm{~N}$ & $\ddagger$ & 0 & 0 & 15 \\
\hline Diagnosis made & IP & IP & IP/Ito & IP Ito & IP & Ito & IP1 & Ito & Ito & 0 & Ito \\
\hline Skin biopsy & + & - & + & + & - & - & - & + & 0 & 0 & 0 \\
\hline $\begin{array}{l}\text { Other features } \\
\text { information }\end{array}$ & & $\begin{array}{l}\text { Bilateral } \\
\text { retinoblastoma }\end{array}$ & & & & & & $\begin{array}{l}\text { Maternally } \\
\text { inherited } \\
\text { translocation }\end{array}$ & & $\begin{array}{l}\text { Non- } \\
\text { dysmorphic }\end{array}$ & $\begin{array}{l}\text { Plexus } \\
\text { papilloma }\end{array}$ \\
\hline $\mathrm{X}$ inactivation (blood) & $\begin{array}{l}>90 \% \mathrm{Xn} \\
\text { inactive }\end{array}$ & $\begin{array}{l}91 \% \mathrm{Xn} \\
\text { inactive }\end{array}$ & $\begin{array}{l}100 \% \mathrm{Xn} \\
\text { inactive }\end{array}$ & $\begin{array}{l}100 \% \mathrm{Xn} \\
\text { inactive }\end{array}$ & 0 & 0 & $\begin{array}{l}92 \% \mathrm{Xn} \\
\text { inactive }\end{array}$ & $\begin{array}{l}100 \% \mathrm{Xn} \\
\text { inactive in } \\
\text { both patient } \\
\text { and mother }\end{array}$ & 0 & 0 & 0 \\
\hline $\mathrm{X}$ inactivation (skin)** & & $\begin{array}{l}>90 \% \mathrm{Xn} \\
\text { inactive }\end{array}$ & $\begin{array}{l}99 \% \mathrm{Xn} \\
\text { inactive }\end{array}$ & 0 & 0 & 0 & 0 & 0 & 0 & 0 & 0 \\
\hline
\end{tabular}

+ present, - absent, 0 not mentioned. N normal. * Moderate cortical atrophy, slight ventricular dilatation (CT scan). † Cerebral cortical atrophy (air encephalography). $\ddagger$ Diffuse corticosubcortical atrophy (CT scan). $\$ Macrocephaly; huge plexus papilloma with enlargement of ventricular system. I The patient's mother carried the same balanced translocation; the mother had seizures as a child but was well and had no pigmentary anomalies. Xn normal, intact X. ${ }^{* *}$ No mention of whether affected/unaffected skin was biopsied (all biopsies cultured and not assayed directly).

centromeric region of the $\mathrm{X}$; while in a majority it is $\mathrm{Xp}$ that is implicated, in three cases $\mathrm{Xq}$ is involved. It is thus unlikely that the same, single locus can be implicated in all these cases, unless the cytogenetic localisation is incorrect in a number of cases. (2) In one case, the X;autosome translocation was familial, being present in both mother and daughter. The mother, however, did not have the pigmentary dysplasia. If the breakpoint in this family were interrupting a critical locus, it might be expected that the mother and daughter would have an identical phenotype.

\section{The effect of functional disomy of sequences on the $X$}

Until recently, it has been difficult to gauge the phenotypic effect of functional disomy of the $\mathrm{X}$ in females. Females who harbour a duplication of material on one $\mathrm{X}$ chromosome are almost invariably normal phenotypically as they have a severely skewed X;inactivation pattern in favour of the intact $\mathrm{X}^{20-22}$ Such females are, however, at $50 \%$ risk of passing on the duplicated chromosome to their sons who invariably have a severe phenotype. At least 15 cases of duplications of the X chromosome in a male karyotype have been reported with the duplications, when considered together, covering most of the $\mathrm{X}$ chromosome, with the exception of Xp11-Xq11 and Xq2526 . $^{20-31}$ The reported cases have a wide range of differing phenotypic abnormalities, although facial dysmorphism, hypotonia, and mental retardation were common, albeit non-specific features. None of these subjects was reported as having a pigmentary dysplasia reminiscent of $\mathrm{HI}$. This is perhaps unsurprising as such subjects are not mosaic. Six people with a duplication encompassing chromosomal region
$\mathrm{Xp} 21$ had sex reversal in addition to the other clinical features mentioned (that is, these were 46,XY females). ${ }^{2628-30}$ Evidence now exists for the presence of a dosage sensitive sex reversal locus (DSS), adjacent to the locus for congenital adrenal hypoplasia at Xp21.2932

Cases of $\mathrm{X}$ chromosome duplication in males are thus instructive in that functional disomy of sequences on the $\mathrm{X}$ is tolerated, albeit with a severe phenotype, related to the presence of functional disomy of $\mathrm{X}$ chromosome sequences (there is evidence that the duplicated segment does not undergo $\mathrm{X}$ inactivation in such cases generally $^{2333}$ ). These males, however, are not mosaic and do not easily allow for prediction of the effect of such disomy in a heterozygous female with random $\mathrm{X}$ inactivation.

The description of a subgroup of females with Turner's syndrome who have a severe phenotype (that is, compared to most Turner patients) in association with a (mosaic) cell that harbours a ring $(\mathrm{X})$ chromosome is, however, instructive. ${ }^{34-38}$ There appears to be a good correlation between the presence of a severe phenotype in such females and the inability of the ring to inactivate, either because the $\mathrm{X}$ inactivation centre is absent, or because XIST expression is defective for reasons that are not entirely clear. ${ }^{353940}$ It seems likely that the clinical severity in these cases is related to the presence of functional disomy of sequences present on the (active) ring. Of particular interest is the fact that a number of such females have been described as possessing a pigmentary dysplasia reminiscent of $\mathrm{HI} .^{34374}$

In addition to the evidence from ring (X) females of the effect of (mosaic) functional disomy of X sequences, another case of a female presenting with $\mathrm{HI}$ is instructive (J Hurst, personal communication). This female presented with seizures, developmental delay, hypo- 
dontia, pigmented whorls on the back, and dysmorphism, including hypertelorism and flat nasal bridge with epicanthic folds. Cytogenetic analysis showed a de novo duplication at $\mathrm{Xp} 11.2$ of the region Xp11.4 $\rightarrow \mathrm{p} 11.2$. $\mathrm{X}$ inactivation analysis in peripheral blood lymphocytes showed random $\mathrm{X}$ inactivation with approximately a 50:50 pattern, rather than the expected skewing towards activity of the intact $\mathrm{X}$. It is likely that the phenotype in this female results from the presence of functional disomy of sequences located in Xp11.2 $\rightarrow 11.4$, in that proportion of cells that have the duplicated $\mathrm{X}$ active. The recognition of this female makes the existence of other females with submicroscopic duplications in the region likely (see below). While functional mosaicism results from random $\mathrm{X}$ inactivation in this female, it is important to note that in the case of $\operatorname{ring}(\mathrm{X})$ females it results from the physical presence or absence of the ring in different cell lineages.

\section{Mosaic functional disomy of $\mathbf{X}$ specific sequences as the most likely mechanism for $\mathrm{HI}$ associated with balanced $\mathbf{X}$;autosome translocations}

What then is the mechanism whereby $\mathrm{HI}$ is manifested in the cases detailed in table 1? A number of possibilities are to be considered.

(1) Interruption of a single locus by the breakpoint on the $X$ chromosome can explain all the cases reported so far. This explanation is unlikely to be true, not only because the reported breakpoints map on both sides of the centromere but molecular evidence also exists for heterogeneity of breakpoints that map to Xp11, implying that at least three of the breakpoints span a distance of $5 \mathrm{Mb}$, a distance greater than that spanned by the largest known human gene, dystrophin. ${ }^{42-45}$ (2) Each breakpoint defines a different locus (homologous in structure or function or both?) that can be implicated in the pathogenesis of HI in these females. Again, this is unlikely. (A) The presence of a discordant phenotype in two females with the same breakpoint (X;10 translocation in table 1) implies that it is the functional status of the derived $\mathrm{X}$ that is important, rather than the precise site of interruption. (B) In the case of the other breakpoints, it is difficult to be certain that a specific locus interruption can be excluded. In the case of the $\mathrm{X} ; 17$ translocation reported by Hodgson et $a l,{ }^{9}$ however, there is mounting evidence against a direct locus interruption. In situ hybridisation analysis has previously shown the $\mathrm{X}$ breakpoint to be centromeric and a recent reanalysis, in addition to confirming the centromeric nature of the $\mathrm{X}$ breakpoint, has shown the 17 breakpoints also to be centromeric, thus making involvement of a locus on 17 unlikely. ${ }^{46}$

(3) The phenotype results from interruption of autosomal loci. This possibility is very difficult to exclude but would appear to be unlikely as a number of different autosomes have now been described in such cases, and in the case of the $\mathrm{X} ; 17$ translocation, the 17 breakpoint is centromeric. In addition, no disruption of an autosomal gene has ever been diagnosed in association with a balanced X;autosome trans- location, probably because most of the resulting phenotypes are recessive. ${ }^{47}$

(4) The phenotype results from an unusual pattern of $X$ inactivation. This seems the most likely explanation and is best exemplified by the case described above in which the phenotype is discordant between mother and daughter, despite identical karyotypes. In a female with a balanced X;autosome translocation, failure to eradicate cell lines bearing an inactive derived $\mathrm{X}$ will result in both mosaic functional disomy of $\mathrm{X}$ sequences and mosaic (variable) functional monosomy of autosomal sequences inactivated by spreading of $\mathrm{X}$ inactivation from the XIC of derived X. By comparison with the cases of ring (X) females, and the female described above with random $\mathrm{X}$ inactivation of a duplicated X chromosome, in both examples of which disomy of the $\mathrm{X}$ is the only possible mechanism, it would seem likely that it is the functional disomy that is the major factor in the females with $\mathrm{HI}$ and X;autosome translocations. Mosaic functional monosomy of autosomal sequences may, however, also be playing a role. While the majority of cases of mosaic aneuploidy described in association with $\mathrm{HI}$ involve the presence of extra chromosomal material, in a small number of cases mosaic monosomy of autosomal sequences has been found. ${ }^{3}$

Recent analysis of the female with a balanced $\mathrm{X} ; 17$ translocation and HI (case 1 of Hodgson et $\mathrm{al}^{9}$ ) showed random $\mathrm{X}$ inactivation in affected (hypopigmented) skin while $\mathrm{X}$ inactivation in normal skin and blood was skewed towards activity of the derived $\mathrm{X}$ as expected. ${ }^{46}$ Such aberrant $\mathrm{X}$ inactivation in affected skin would result in functional disomy for all of $\mathrm{Xp}$ and a variable portion of $17 p$ in those cells with an inactive derived $\mathrm{X}$.

However, the phenotypic overlap between $\operatorname{ring}(\mathrm{X})$ females and those with $\mathrm{HI}$ associated with balanced $\mathrm{X}$;autosome translocations makes disomy the most likely mechanism. Van Dyke $e t a l^{\beta 7}$ found that pigmentary dysplasia was associated with the presence of a small ring (X) in females with a severe phenotype (in at least $19 \%$ of cases). Indeed, the female described by de Grouchy et $a l^{41}$ was thought to have incontinentia pigmenti; Xp11 was again put forward as a region likely to contain the locus for incontinentia pigmenti as one of the breakpoints was in this region. It would seem preferable to reclassify this female as having HI associated with a small ring $(\mathrm{X})$ chromosome that failed to inactivate (the ring $(\mathrm{X})$ was found never to be late labelling).

Many of the dysmorphic features found in females with small ring $(\mathrm{X})$ chromosomes are also frequent in females with $\mathrm{HI}$ associated with $\mathrm{X}$; autosome translocations (tables 2 and 3 ).

\section{$X$;autosome translocations and $X$ linked disorders: theoretical reasons for IP1/H1 females not having classical} incontinentia pigmenti The discovery of rare females manifesting $\mathrm{X}$ linked phenotypes in association with a balanced, constitutional X;autosome trans- 
Table 2 List of dysmorphic features reported in females with HI associated with balanced X;autosome translocations, graded according to frequency. Note overlap with ring $(X)$ cases (see table 3 ).

\begin{tabular}{|c|c|c|c|c|c|c|c|c|c|c|c|}
\hline & $X ; 17^{9}$ & $X ; 9^{9}$ & $X ; 13^{10}$ & $X ; 10^{7}$ & $X ; 9^{8 *}$ & $X ; 18^{58} \dagger$ & $X ; 5^{6}$ & $X ; 10^{59}$ & $X ; 14^{60} \dagger$ & $X ; 22^{3 *}$ & $X ; 17^{61}$ \\
\hline High arched palate $(4 / 11)$ & + & & + & & & & + & + & & & \\
\hline Broad nasal bridge $(3 / 11)$ & + & & + & & & & + & & & & \\
\hline HC $>95$ th centile $(3 / 11)$ & + & + & & & & & & & & & + \\
\hline Abnormal ears (3/11) & + & & + & + & & & & & & & \\
\hline High forehead $(3 / 11)$ & + & & & & & & + & + & & & \\
\hline Dental abnormalities $(3 / 11)$ & & + & & & & & & + & & & \\
\hline Flat face $(2 / 11)$ & & & & & & & + & & & & \\
\hline Hypertelorism (2/11) & + & & & + & & & & & & & \\
\hline Epicanthic folds $(2 / 11)$ & + & & & + & & & & & & & \\
\hline Small hands and feet $(2 / 11)$ & + & & & & & & & + & & & \\
\hline Brachycephaly $(1 / 11)$ & & + & & & & & & & & & \\
\hline Prognathism $(1 / 11)$ & & + & & & & & & & & & \\
\hline Large tongue $(1 / 11)$ & & + & & & & & & & & & \\
\hline Plagiocephaly $(1 / 11)$ & + & & & & & & & & & & \\
\hline Carp shaped mouth $(1 / 11)$ & & & + & & & & & & & & \\
\hline Syndactyly $(1 / 11)$ & & & & + & & & & & & & \\
\hline Short philtrum (1/11) & & & & + & & & & & & & \\
\hline Cleft soft palate $(1 / 11)$ & & & & + & & & & & & & \\
\hline Hirsutism $(1 / 11)$ & + & & & & & & & & & & \\
\hline Gum hypertrophy $(1 / 11)$ & + & & & & & & & & & & \\
\hline Neonatal teeth $(1 / 11)$ & & & & + & & & & & & & \\
\hline Alopecia $(1 / 11)$ & & & & & & & + & & & & \\
\hline
\end{tabular}

* Dysmorphic features noted as being absent. + No mention made of dysmorphic features. With the exception of cases $5,6,9$, and 10 , a blank indicates that the relevant feature was not observed.

location has been of great benefit in the localisation and isolation of the loci involved in such disorders. ${ }^{48-50}$ The manifestation of the relevant $\mathrm{X}$ linked disorder in such females is thought to result from the severe skewing of $\mathrm{X}$ inactivation that is usually observed. While $\mathrm{X}$ inactivation in such females probably occurs randomly, subsequent selection against cells that have inactivated the derived $X$ chromosome results in a uniform pattern of inactivation in which the intact $\mathrm{X}$ is almost invariably the inactive one. Interruption of the $\mathrm{X}$ linked locus under consideration on the derived $X$ renders the female functionally nullisomic and the phenotype is therefore manifest. While it is usually assumed that cell selection is primarily directed against cells that have an inactive derived $\mathrm{X}$ because of spreading of inactivation onto the attached autosome, it is likely that functional disomy of $\mathrm{X}$ sequences is an equally potent abnormality against which selection occurs (fig 1). ${ }^{47}$

Females with $\mathrm{X}$ linked phenotypes resulting from balanced $\mathrm{X}$; autosome translocations manifest those phenotypes precisely because of the severe skewing that renders them "malelike". Thus it would be surprising, a priori, to discover females manifesting an $\mathrm{X}$ linked dominant disorder with male lethality (such as IP2) in association with a balanced X;autosome

Table 3 Dysmorphic features reported in three females with a pigmentary dysplasia associated with the presence of a ring $(X)$ cell line, graded according to frequency. The most common features overlap with the most common features described in the $X$;autosome cases

\begin{tabular}{llll}
\hline & $\begin{array}{l}\text { Case 3 of Dennis } \\
\text { et a } l^{34}\end{array}$ & $\begin{array}{l}\text { Case 5 of Van } \\
\text { Dyke et al }{ }^{37}\end{array}$ & $\begin{array}{l}\text { de Grouchy } \\
\text { et al } l^{41}\end{array}$ \\
\cline { 2 - 4 } & $r(X)$ & $r(X)$ & $r(X)$ \\
\hline $\begin{array}{l}\text { Broad nasal bridge (3/3) } \\
\text { Hypertelorism (3/3) }\end{array}$ & + & + & + \\
High arched palate (2/3) & + & + & + \\
Abnormal ears (2/3) & + & + & + \\
Epicanthic folds (2/3) & + & + & + \\
HC>95th centile (1/3) & + & + & \\
$\begin{array}{l}\text { Syndactyly (1/3) } \\
\text { Heart malformation (1/3) }\end{array}$ & + & + & + \\
Polydactyly (1/3) & & + & + \\
Alopecia (1/3) & & & + \\
\hline
\end{tabular}

translocation. In addition, one would predict that females manifesting $\mathrm{X}$ linked disorders in association with $\mathrm{X}$;autosome translocations would not have a mosaic pattern of expression. For example, the pattern of disease expression in IP2 is characterised by the presence of abnormal skin alongside normal skin, the demarcation being along Blaschko's lines. Such "phenotypic mosaicism" is likely to arise because of random $\mathrm{X}$ inactivation during development; abnormal skin presumably contains large numbers of cells with the mutation bearing $\mathrm{X}$ active while normal skin has this chromosome inactivated. Such phenotypic mosaicism is known to occur in females who are obligate heterozygotes for a number of $\mathrm{X}$ linked disorders, including hypohidrotic ec-
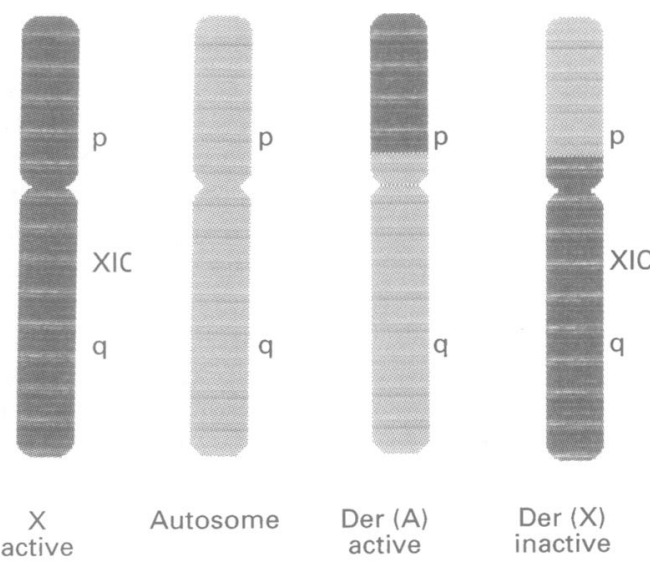

\section{$\mathrm{XIC}=\mathrm{X}$ inactivation centre}

Figure 1 This figure illustrates the situation in those cells that have failed to inactivate in the usual way. The intact $X$ is active, while the derived $X$ is inactive. Two functionally active copies of $X p$ (that is, of all sequences distal to the breakpoint in the pericentromeric region of the $X)$ are therefore present, one on the intact $X$ and one on $X)$ are therefore present, one on the intact $X$ and one on
the derived autosome. The latter $X p$ is presumed to remain functional as it has been physically disconnected from the $X I C$ of the derived $X$. In addition to functional disomy of $X p$, it is likely that there will be a (variable) monosomy of autosomal sequences owing to spreading of inactivation from the XIC of the inactive derived X. 
todermal dysplasia, Menkes disease, and Goltz syndrome. ${ }^{51}$ Thus, not only do significant differences exist between the phenotypes described in IP1 and those of "classical" IP (IP2) but there are more fundamental reasons why the females with IP1 are unlikely to have the same locus implicated as those with IP2. This argument predicts that no female will be described who has "incontinentia pigmenti" in association with an X;autosome translocation involving the IP2 locus at Xq28. In addition, it argues against the likelihood that any of the $\mathrm{X}$ breakpoints in females with $\mathrm{HI}$ associated with a balanced X;autosome translocation involve a locus that defines a familial disorder.

\section{Specific reasons for IP1/HI breakpoints not being related to incontinentia pigmenti}

It would now seem clear that the phenotypic differences between IP1/HI and IP2 are sufficient to warrant the designation IP1 redundant. ${ }^{17}$ In addition to the differences in evolution of skin abnormalities between the two conditions, most of the females with IP1/ HI have been noted to be dysmorphic (table 2), a feature not present in classical familial incontinentia pigmenti. ${ }^{16}$

\section{Functional disomy of $\mathbf{X}$ sequences in diploid/triploid mixoploidy as a mechanism for $\mathrm{HI}$ ?}

HI has been described in association with diploid/triploid mixoploidy. It is tempting to speculate that functional disomy of $\mathrm{X}$ sequences may also be implicated in the pathogenesis here. In cells that have more than one $\mathrm{X}$ chromosome, it is invariably the case that one $\mathrm{X}$ remains active, while all others are inactivated. This is true for diploid cells, irrespective of the number of $\mathrm{X}$ chromosomes present. Triploid cells, however, appear able to support the activity of more than one $\mathrm{X}$ chromosome. Thus, while only one $\mathrm{X}$ is active in $47, \mathrm{XXY}$ cells, $69, \mathrm{XXY}$ cells may have two active $\mathrm{X}$ chro-

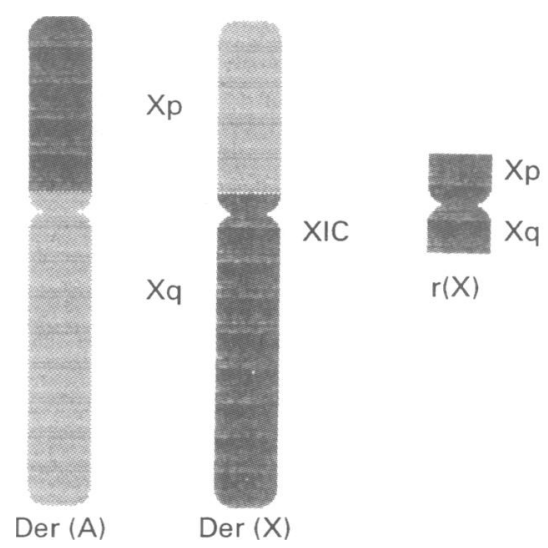

Region of overlap within which disomy
may give rise to $\mathrm{HI}$

Figure 2 Diagram illustrating the possible location of a locus/loci that causes the HI phenotype when present in a functionally disomic form. Given that quite a number of females have now been described who manifest a severe phenotype in association with a small ring $X$ chromosome, it should be possible to define this region more precisely. Any such locus, according to the hypothesis, should map distal to the most "telomeric"; IPI $X$;autosome translocation breakpoint, and proximal to the most "centromeric" of all the $X p$ ring $X$ breakpoints. mosomes. ${ }^{52}$ It seems likely that it is the ratio of autosomes to $\mathrm{X}$ that determines the number of $\mathrm{X}$ chromosomes that will remain active, with a usual diploid complement of 44 autosomes ensuring that only one $X$ remains active. In the case of $69, \mathrm{XXX}$ or $69, \mathrm{XXY}$ triploidy, a proportion of cells will harbour more than one active $\mathrm{X}$ chromosome, with the result that these cells will be functionally disomic for the whole of the $\mathrm{X}$, a situation that is likely to be deleterious to the cell line under consideration. Clearly, however, the presence of an extra set of autosomes cannot be ruled out as being implicated in the pathogenesis of $\mathrm{HI}$ in these people.

\section{Can specific $\mathbf{X}$ linked loci be defined which are necessary for development of HI resulting from functional disomy of the $X$ ?}

It is probable that the females ascertained as having $\mathrm{HI}$ in association with $\mathrm{X}$;autosome translocations with breakpoints in Xq13-Xp11 represent a small minority of all females with such translocations. In a recent review of 122 published cases of balanced X;autosome translocations in females, the breakpoints in 57 were listed as lying above XIC. ${ }^{47}$ Of these, 20 were said to be phenotypically normal and it is to be expected that the true proportion is even higher as such phenotypically normal females are much less likely to be ascertained. In the majority of cases, the breakpoints are unlikely to interrupt specific loci and skewed $\mathrm{X}$ inactivation will result in a normal phenotype. There is unlikely to be a specific reason for ineffective selection against cells bearing an inactive derived $\mathrm{X}$. In their review, Schmidt and Du Sart ${ }^{47}$ reported that inactivation of the derived $\mathrm{X}$, in at least some tissues, occurs in $23 \%$ of females with balanced X;autosome translocations.

However, no females have been described with $\mathrm{HI}$ where the $\mathrm{X}$ breakpoint lies outside $\mathrm{Xq13-Xp11.} \mathrm{It} \mathrm{is} \mathrm{noteworthy} \mathrm{that,} \mathrm{of} 24 \mathrm{fe}-$ males known to manifest Duchenne muscular dystrophy in association with a balanced X; autosome translocation that disrupts the DMD locus, none has been described as having a pigmentary dysplasia, although a number have other abnormalities, including psychomotor retardation. ${ }^{53}$ Thus it seems likely that if specific loci are to be implicated in the pathogenesis of $\mathrm{HI}$, when present in a functionally disomic state, then such loci must be located proximal to $\mathrm{Xp} 21$. In addition, the presence of $\mathrm{HI}$ in females with small ring (X) chromosomes, in whom functional disomy is almost certainly the aetiological mechanism, argues for the presence of the implicated locus (loci) within the ring.

Thus, the locus (loci) in question may be mapped by considering the smallest ring (X) found to cause $\mathrm{HI}$ and the most distal $\mathrm{X}$ breakpoint that also gives rise to the phenotype (fig 2). However, although such analysis may define a minimum region within which such a locus (loci) must reside, it is conceivable that different loci may be responsible in different cases. 
Why are no $X$ breakpoints described below Xq13?

Inactivation of the derived $\mathrm{X}$ in a cell bearing an $\mathrm{X}$;autosome translocation with a breakpoint below Xq13 will result in functional disomy of $\mathrm{Xq}$ sequences. The absence of $\mathrm{X}$ breakpoints below Xq13 argues against functional disomy of $\mathrm{Xq}$ sequences as being important in production of the HI phenotype. If a locus (loci) on $\mathrm{Xp}$ is particularly important in the production of the $\mathrm{HI}$ phenotype (that is, in a functionally disomic state), then only breakpoints above the XIC will be ascertained in this way.

\section{$X$;autosome translocations and mapping XLMR genes}

Failure to eradicate cell lines bearing an inactive derived X may happen in some tissues and not others. Thus, it is likely that some females with mental retardation associated with balanced $\mathrm{X}$;autosome translocations, in whom a pigmentary dysplasia is absent, may still be manifesting their phenotype as a result of the mechanism outline above (that is, in those cases where the breakpoint lies above XIC). In such females, eradication of cell lines bearing an inactive derived $\mathrm{X}$ may have been successful in skin but not in other tissues, such as CNS. It is possible that such females will be erroneously interpreted as possessing a translocation that results in the interruption of a locus for $\mathrm{X}$ linked mental retardation (XLMR). This is likely to be a potential hazard in the mapping and isolation of genes implicated in XLMR, particularly where this is non-syndromic. The case described by Hodgson et $a \bar{l}^{4}$ illustrates the point. A female with a balanced, de novo, constitutional X;13 translocation was described as developmentally delayed and dysmorphic. No pigmentary dysplasia was noted but her dysmorphic features, albeit relatively non-specific, were consistent with those seen in the females described above. Others have noted an increased incidence of breakpoints at Xp11 in females with mental retardation and X;autosome translocations and correlated this with XLMR loci thought to map to this region. ${ }^{55}$

\section{Functional disomy of $\mathrm{Xp}$ in} cytogenetically normal females with HI? It is likely that females exist with submicroscopic duplications in $\mathrm{Xp}$, who manifest the phenotype of HI. Indeed, this may be one possible mechanism to explain the rare reported cases of familial HI. ${ }^{56}$ The presence of a submicroscopic duplication on one $\mathrm{X}$ may result in a variety of phenotypes depending on the pattern of $\mathrm{X}$ inactivation in relevant tissues. A phenotypically normal mother (or one who simply had a pigmentary dysplasia) might have a severely affected daughter with $\mathrm{HI}$ and CNS abnormalities. It is harder to explain familial occurrences of $\mathrm{HI}$ by implicating submicroscopic autosomal abnormalities, as there is not as much scope for phenotypic variability as is afforded by differential $\mathrm{X}$ inactivation. It is suggested that a search for submicroscopic duplications in proximal Xp may be fruitful in female cases of $\mathrm{HI}$ where cytogenetic analysis is normal, particularly if there are indications that the HI may be familial, albeit with variable severity.

\section{Conclusion}

This review has presented evidence for the role of functional disomy of $\mathrm{Xp}$ in the pathogenesis of $\mathrm{HI}$ associated with $\mathrm{X}$;autosome translocations with breakpoints in the pericentromeric region of the $\mathrm{X}$. Previous ideas about such $\mathrm{X}$ breakpoints defining specific loci are likely to be false for reasons stated above.

Further work to map minimal regions of overlap found in (A) ring (X) cases and (B) translocation cases may define a locus (loci) that is implicated in the pathogenesis of $\mathrm{HI}$ and may lead to the discovery of patients with $\mathrm{HI}$ resulting from submicroscopic duplications.

In addition, caution is required when interpreting the pathogenesis of mental retardation in females with balanced X;autosome translocations and it should not be assumed that the $\mathrm{X}$ breakpoint necessarily defines a locus implicated in XLMR. The obvious exceptions will include females who manifest a well defined phenotype in association with a balanced $\mathrm{X}$;autosome translocation (for example, Menkes syndrome, see above).

\section{Implications for genetic counselling}

While the majority of females with balanced $\mathrm{X}$;autosome translocations with breakpoints above XIC are likely to be phenotypically normal, accurate prediction of the phenotype of any daughters with an identical translocation cannot be made with certainty, as "unfortunate" $\mathrm{X}$ inactivation may result in a severe phenotype as illustrated by the maternally inherited X;10 translocation detailed in table 1. Conversely, where a phenotypically normal mother with a balanced X;autosome translocation has a son with the same balanced translocation, reassurance can be given that the child will be phenotypically normal although male infertility would be expected. ${ }^{57}$ In this situation the presence of a normal phenotype in the mother makes interruption of a specific locus on either the $\mathrm{X}$ or the autosome unlikely, so that there is no specific reason why male offspring should have an abnormal phenotype.

I am grateful to Nick Dennis and Pat Jacobs for helpful comments. This work was supported by the Wellcome Foundation.

1 Ito $\mathrm{M}$. Incontinentia pigmenti achromians. A singular case of nevus depigmentosus systematicus bilateralis. Tohoku Exp Med (Sendai) 1952;55 (suppl):57-9.

2 Donnai D, Read AP, McKeown C, Andrews T. Hypomelanosis of Ito: a manifestation of mosaicism or chimerism. 7 Med Genet 1988;25:809-18.

3 Sybert VP, Pagon RA, Donlan M, Bradley CM. Pigmentary abnormalities and mosaicism for chromosomal aberration: abnormalities and mosaicism for chromosomal aberration: association with clinical features

4 Takematsu $H$, Sato S, Igarashi M, Seiji M Incontinentia pigmenti achromians (Ito). Arch Dermatol 1983;119:391-

5 Cohen MJ. Proteus syndrome: clinical evidence for somatic mosaicism and selective review. Am F Med Genet 1993 47:645-52

6 Bitoun P, Philippe C, Cherif M, Mulcahy MT, Gilgenkrantz $\mathrm{S}$. Incontinentia pigmenti (type 1) and $\mathrm{X} ; 5$ translocation Ann Genet (Paris) 1992;35:51-4. 
7 Cannizzaro LA, Hecht F. Gene for incontinentia pigmenti maps to band Xp11 with an $(\mathrm{X} ; 10)(\mathrm{pl1} 1 \mathrm{q} 22)$ translocation. Clin Genet 1987;32:66-9.

8 Gilgenkrantz S, Tridon P, Pinel BN, Beurey J, Weber $M$. Translocation $(\mathrm{X} ; 9)(\mathrm{p} 11 ; \mathrm{q} 34)$ in a girl with incontinentia pigmenti (IP): implications for the regional assignment of the IP locus to Xp11? Ann Genet (Paris) 1985;28:90-2.

9 Hodgson SV, Neville B, Jones RW, Fear C, Bobrow M. Two cases of $\mathrm{X}$ /autosome translocation in females with incontinentia pigmenti. Hum Genet 1985;71:231-4

10 Kajii T, Tsukahara M, Fukushima Y, Hata A, Matsuo K, Kuroki Y. Translocation (X;13) (p11.21;q12.3) in a girl with incontinentia pigmenti and bilateral retinoblastoma. Ann Genet (Paris) 1985;28:219-23.

11 Sefiani A, Sinnett D, Abel L, et al. Linkage studies do not confirm the cytogenetic location of incontinentia pigmenti on Xp11. Hum Genet 1988;80:282-6.

12 Sefiani A, Abel L, Heuertz S, et al. The gene for incontinentia pigmenti is assigned to Xq28. Genomics $1989 ; 4: 427-9$.

13 Sefiani A, M'rad R, Simard L, et al. Linkage relationship between incontinentia pigmenti (IP2) maps to the distal part of Xq28. Hum Genet 1993:3:273-8.

14 Smahi A, Hyden GC, Peterlin B, et al. The gene for the familial form of incontinentia pigmenti (IP2) maps to the distal part of Xq28. Hum Mol Genet 1994;3:273-8.

15 Harris A, Lankester S, Haan E, et al. The gene for incontinentia pigmenti: failure of linkage studies using DNA probes to confirm cytogenetic localization. Clin Genet 1988;34:1-6.

16 Landy SJ, Donnai D. Incontinentia pigmenti (Bloch-Sulzberger syndrome). 7 Med Genet 1993;30:53-9.

17 Sybert VP. Incontinentia pigmenti nomenclature. Am f Hum Genet 1994;55:209-11.

18 Thomas IT, Frias J, Cantu ES, Lafer CZ, Flannery DB Graham JJ. Association of pigmentary anomalies with chromosomal and genetic mosaicism and chimerism. $A m$ f Hum Genet 1989;45:193-205.

19 Donnai D, McKeown C, Andrews T, Read AP. Diploid triploid mixoploidy and hypomelanosis of Ito. Lancet 1986 i: $1443-4$.

20 Nielsen $\mathrm{KB}$, Langkjaer $\mathrm{F}$. Inherited partial X chromosome duplication in a mentally retarded male. $\mathcal{f}$ Med Genet 1982;19:222-4.

21 Schwartz S, Schwartz MF, Panny SR, Peterson CJ, Waters $\mathrm{E}, \mathrm{Cohen} \mathrm{MM}$. Inherited X-chromosome inverted tandem duplication in a male traced to a grandparental mitotic error (published erratum appears in $\mathrm{Am} \mathcal{F}$ Hum Genet 1987;40:297). Am ₹ Hum Genet 1986;38:741-50.

22 Vejerslev LO, Rix M, Jespersen B. Inherited tandem duplication $\operatorname{dup}(\mathrm{X})(\mathrm{q} 131-\mathrm{q} 212)$ in a male proband. Clin Genet 1985;27:276-81.

23 Schmidt M, Du SD, Kalitsis P, et al. Duplications of the X chromosome in males; evidence that most parts of the $\mathrm{X}$ chromosome can be active in two copies. Hum Genet 1991; 86:519-21.

24 Thode A, Partington MW, Yip MY, Chapman C, Richardson VF, Turner G. A new syndrome with mental retardation, short stature and an Xq duplication. $A m \mathcal{F}$ Med Genet 1988;30:239-50.

25 Steinbach P, Horstmann W, Scholz W. Tandem duplication $\operatorname{dup}(X)(\mathrm{q} 13 \mathrm{q} 22)$ in a male proband inherited from the mother showing mosaicism of X-inactivation. Hum Genet 1980;54:309-13.

26 Scherer G, Schempp W, Baccichetti C, et al. Duplication of an Xp segment that includes the ZFX locus causes sex inversion in man. Hum Genet 1989;81:291-4.

27 Cremers FP, Pfeiffer RA, van de Pol, TJ et al An interstitial duplication of the $\mathrm{X}$ chromosome in a male allows physical fine mapping of probes from the Xq13-q22 region. Hum Genet 1987;77:23-7.

28 Bernstein R, Jenkins T, Dawson B, et al. Female phenotype and multiple abnormalities in sibs with a Y chromosome and partial $\mathrm{X}$ chromosome duplication: $\mathrm{H}-\mathrm{Y}$ antigen and Xg blood group findings. 7 Med Genet 1980;17:291-300.

29 Rao PN, Klinepeter K, Stewart W, Hayworth R, Grubs R, Pettenati MJ. Molecular cytogenetic analysis of a duplication $\mathrm{Xp}$ in a male: further delineation of a possible sex influencing region on the X chromosome. Hum Genet 1994;94:149-53.

30 Reichenbach $\mathrm{H}$, Holland $\mathrm{H}$, Thamm B, Theile T. Multiple abnormalities in a child with male karyotype due to familial partial Xp duplication. (German.) Kinderaztliche Praxi 1993;61:291-5.

31 Muscatelli F, Verna JM, Philip N, et al. Physical mapping of an Xq-proximal interstitial duplication in a male. Hum Genet 1992;88:691-4.

32 Bardoni B, Zanaria E, Guioli S, et al. A dosage sensitive locus at chromosome $\mathrm{Xp} 21$ is involved in male to female sex reversal. Nature Genet 1994;7:497-501.

33 Muscatelli F, Lena D, Mettei MG, Fontes M. A male with two contiguous inactivation centers on a single $\mathrm{X}$ chromosome: study of $\mathrm{X}$ inactivation and $\mathrm{XIST}$ expression. Hum Mol Genet 1992;1:115-9.

34 Dennis NR, Collins AL, Crolla JA, Cockwell AE, Fisher $\mathrm{AM}$, Jacobs PA. Three patients with ring $(\mathrm{X})$ chromosomes and a severe phenotype. F Med Genet 1993;30:482-6.

35 Cole H, Huang B, Salbert BA, et al. Mental retardation and Ullrich-Turner syndrome in cases with $45, \mathrm{X} / 46, \mathrm{X}$, + mar: additional support for the loss of the $\mathrm{X}$-inactivation center hypothesis. Am f Med Genet 1994;52:136-45.

36 Grompe M, Rao N, Elder FF, Caskey CT, Greenberg F. $45, \mathrm{X} / 46, \mathrm{X}, \mathrm{r}(\mathrm{X})$ can have a distinct phenotype different from Ullrich-Turner syndrome. Am $\mathcal{F}$ Med Genet 1992; 42:39-43.

37 Van Dyke D, Wiktor A, Palmer CG, et al. Ullrich-Turner syndrome with a small ring X chromosome and presence
of mental retardation. Am $\mathcal{F}$ Med Genet 1992;43:996-1005. 38 Wolff DJ, Brown CJ, Schwartz S, Duncan AM, Surti U, Willard HF. Small marker X chromosomes lack the X inactivation center: implications for karyotype/phenotype correlations. Am $\mathcal{F}$ Hum Genet 1994;55:87-95.

39 Migeon BR, Luo S, Stasiowski BA, et al. Deficient transcription of XIST from tiny ring $\mathrm{X}$ chromosomes in females with severe phenotypes. Proc Natl Acad Sci USA 1993;90:12025-9.

40 Migeon BR, Luo S, Jani M, Jeppesen P. The severe phenotype of females with tiny ring $\mathrm{X}$ chromosomes is associated with inability of these chromosomes to undergo $\mathrm{X}$ inactivation. Am f Hum Genet 1994:55:497-504.

41 de Grouchy J, Turleau C, Doussau DBM, Maroteaux P, Thibaud D. Incontinentia pigmenti (IP) and $r(X)$. Tentative mapping of the IP locus to the $\mathrm{X}$ juxtacentromeric ative mapping of the IP locus to the X

42 Reed V, Rider S, Maslen GL, et al. A 2-Mb YAC contig encompassing three loci (DXF34, DXS14, and DXS390) that lie between Xp11.2 translocation breakpoints associated with incontinentia pigmenti type 1. Genomics 1994;20:341-6.

43 Gorski JL, Burright EN, Harnden CE, Stein CK, Glover TW, Reyner EL. Localization of DNA sequences to a region within Xp11.21 between incontinentia pigmenti (IP1) $\mathrm{X}$ chromosomal translocation breakpoints. $A m \mathcal{F}$ Hum Genet 1991;48:53-64.

44 Hatchwell E, Bitoun P, Gilgenkrantz S, et al. Incontinentia pigmenti translocation breakpoints - further evidence for heterogeneity. Accepted for oral presentation at Chromosome Specific Session, Human Gene Mapping Workshop, Kobe, Specific Session

45 Hatchwell E, Bitoun P, Gilgenkrantz S, et al. Further evidence for heterogeneity of IP1/HI breakpoints (in preparation)

46 Hatchwell E, Robinson D, Crolla JA, Cockwell AE. X inactivation analysis in a female with hypomelanosis of Ito associated with a balanced $\mathrm{X} ; 17$ translocation: evidence for functional disomy of Xp. F Med Genet 1996;33:216-20.

47 Schmidt $M$, Du Sart D. Functional disomies of the $X$ chromosome influence the cell selection and hence the $\mathrm{X}$ inactivation pattern in females with balanced $\mathrm{X}$-autosome translocations: a review of 122 cases. Am $f$ Med Genet 1992;42:161-9.

48 Attree O, Olivos IM, Okabe I, et al. The Lowe's oculocerebrorenal syndrome gene encodes a protein highly homologous to inositol polyphosphate-5-phosphatase. homologous to inositol

49 Chelly J, Tumer Z, Tonnesen T, et al. Isolation of a candidate gene for Menkes disease that encodes a potential heav metal binding protein. Nature Genet 1993;3:14-19.

50 Ray PN, Belfall B, Duff C, et al. Cloning of the breakpoint of an X;21 translocation associated with Duchenne muscular dystrophy. Nature 1985;318:672-5.

51 Happle R. Lyonization and the lines of Blaschko. Hum Genet 1985;70:200-6.

52 Weaver DD, Gartler SM. Evidence for two active X chromosomes in a human XXY triploid. Humangenetik 1975 28:39-42.

53 Boyd Y. In: Roses C, ed. Molecular genetics and neurology London: Royal Society of Medicine, 1991.

54 Hodgson SV, Barber JC, Dowie A, Dubowitz V. A de novo $\mathrm{X} ; 13$ translocation with abnormal phenotype. $f$ Med Genet 1986;23:477-8.

55 Teboul M, Mujica P, Chery M, Leotard B, Gilgenkrantz S Balanced X-autosomal translocation and mental retardation. Mapping mental retardation linked to $\mathrm{X}(\mathrm{ex}$ cluding fragile X). (French.) f Genet Hum 1989;37: 179-95

56 Montagna P, Procaccianti G, Galli G, Ripamonti L, Patrizi A, Baruzzi A. Familial hypomelanosis of Ito. Eur Neurol 1991:31:345-7.

57 Carpenter NJ. Balanced X;autosome translocations and gonadal dysfunction in females and males. In: Sandberg AA, ed. Cytogenetics of the mammalian X chromosome. Part B. Volume 3. New York: Alan R Liss, 1983:211-24.

58 Lungarotti MS, Martello C, Calabro A, Baldari F, Mariotti $\mathrm{G}$. Hypomelanosis of Ito associated with chromosomal translocation involving Xp11. Am 7 Med Genet 1991;40: translocati

59 Koiffmann CP, De SD, Diament A, et al. Incontinentia pigmenti achromians (hypomelanosis of Ito, MIM 146150): further evidence of localization at Xp11. Am $\mathcal{F}$ Med Genet 1993;46:529-33.

60 Penchaszadeh VB, Babu A, Schwartz M, David KL, Popescu $\mathrm{S}$, Rubinstein C. Hypomelanosis of Ito in a girl with a de novo translocation $(\mathrm{X} ; 14)(\mathrm{q} 11 ; \mathrm{q} 13)$. Am f Hum Genet Suppl 1989;45:A219.

61 Steichen GE, Trawoger R, Duba HC, Mayr U, Felber S, Utermann G. Hypomelanosis of Ito in a girl with plexus papilloma and translocation (X;17). Hum Genet 1993;90: 